\title{
PENERAPAN MODEL PEMBELAJARAN TPS UNTUK MENINGKATKAN HASIL BELAJAR IPA SISWA KELAS V SD NO 1 MENGWITANI
}

\author{
I.W. Daniel Winantara \\ Jurusan Pendidikan Guru Sekolah Dasar, Fakultas IImu Pendidikan \\ Universitas Pendidikan Ganesha \\ Singaraja, Indonesia \\ e-mail: danielwinantara28@gmail.com
}

\begin{abstract}
Abstrak
Tujuan penelitian ini untuk mengetahui peningkatan hasil belajar IPA siswa kelas V SD No. 1 Mengwitani setelah diterapkannya model pembelajaran think pair share (TPS). Penelitian ini adalah penelitian tindakan kelas yang dilakukan dalam dua siklus. Subjek dalam penelitian ini adalah siswa kelas $\mathrm{V}$ yang berjumlah 32 orang. Data penelitian ini tentang hasil belajar yang dikumpulkan dengan menggunakan metode tes. Data dianalisis dengan menggunakan statistik kuantitatif. Hasil penelitian menunjukkan adanya peningkatan terhadap hasil belajar IPA siswa kelas V SD No. 1 Mengwitani. Hal ini ditunjukkan dengan hasil penelitian yang diperoleh yaitu persentase rata-rata hasil belajar pada siklus I sebesar 75,31\% yang berada pada kategori sedang dan pada siklus II menjadi $80,15 \%$ yang berada pada kategori tinggi. Dengan ketuntasan belajar siswa pada siklus I sebesar $65,62 \%$ dan pada siklus II mencapai $87,5 \%$. Berdasarkan hasil penelitian tersebut dapat disimpulkan penerapan model pembelajaran think pair share dapat meningkatkan hasil belajar IPA siswa kelas $\mathrm{V}$ SD No. 1 Mengwitani.
\end{abstract}

Kata kunci: Model Pembelajaran Think Pair Share, Hasil Belajar

\section{Pendahuluan}

Dalam isi pembukaan UndangUndang Dasar 1945 terdapat sepenggal kalimat yang berbunyi "ikut mencerdaskan kehidupan bangsa dan ikut melaksanakan ketertiban dunia". Untuk mencerdaskan kehidupan suatu bangsa, terlebih lagi individu-individu yang ada di dalamnya, yang merupakan roda penggerak dari suatu bangsa maka pendidikan adalah hal mutlak yang diperlukan. Pendidikan sekarang ini bukanlah suatu barang langka dan mahal yang hanya dapat dirasakan oleh orang-orang yang mampu. Namun, kini pendidikan bagaikan sebuah keharusan atau kebutuhan inti setiap orang disamping makanan. Menurut UUD 1945 Nomor 20 tahun 2003 tentang Sistem Pendidikan Nasional disebutkan bahwa Pendidikan adalah usaha sadar dan terencana untuk mewujudkan suasana belajar dan proses pembelajaran agar peserta didik secara aktif mengembangkan potensi dirinya untuk memiliki kekuatan spiritual keagamaan, pengendalian diri, kepribadian, kecerdasan, akhlak mulia, serta keterampilan yang diperlukan dirinya, masyarakat, bangsa dan negara.

Pendidikan tidak hanya didapat di lembaga khusus yang menangani pendidikan namun juga di rumah, dimana peserta didik atau siswa menghabiskan waktunya lebih lama. Pada masa yang telah lalu, sebelum lembaga pendidikan formal didirikan, pendidikan hanya diberikan oleh orang tua kepada anaknya. Isi dari pendidikan yang diberikanpun hanyalah pendidikan ahlak, agama, budi pekerti dan hal-hal yang berguna bagi kehidupannya.

Pendidikan yang sejati adalah pendidikan yang memanusiakan manusia, dalam arti pendidikan membuat atau membentuk karakter manusia yang sesungguhnya. Untuk itu diperlukan berbagai komponen pendukung dalam pendidikan untuk menciptakan generasi penerus bangsa yang mampu bersaing di dunia global diera-era berikutnya. 
Dalam pelaksanaannya, guru menjadi salah satu ujung tombak dalam mengeksekusi kegiatan-kegiatan yang dapat memajukan pendidikan nasional. Guru yang menjadi ujung tombak pelaksanaan pendidikan nasional haruslah professional. Kurniasih dan Berlin Sani (2016) menyatakan "Guru professional adalah semua orang yang mempunyai kewanangan serta bertanggung jawab tentang pendidikan anak didiknya, baik secara individual atau klasikal, di sekolah atau di luar sekolah".

Hasil belajar siswa yang tinggi dalam proses pembelajaran diperlukan dalam setiap mata pelajaran. Hal ini dapat menjadi salah satu indikator kebehasilan dalam proses pelaksanan kegiatan pembelajaran. Hal ini juga diperlukan dalam kegiatan pembelajaran IImu Pengetahuan Alam. IImu Pengetahuan Alam sebagai sebuah disilplin ilmu dan penerapannya dalam masyarakat membuat pendidikan IPA menjadi penting. Haryono (2013) menyatakan "dalam kegiatan pembelajarannya peserta didik diberikan kesempatan untuk berlatih keterampilan-keterampilan IPA, sebab diharapkan mereka dapat berpikir dan memiliki sikap ilmiah". Selanjutnya, Paolo dan Marten (dalam Haryono, 2013) juga menegaskan "di dalam IPA tercakup juga coba-coba dan melakukan kesalahan, gagal, dan mencoba lagi. IImu Pengetahuan Alam tidak menyediakan semua jawaban untuk masalah yang diajukan sehingga guru dan siswa harus tetap bersikap skeptis sehingga selalu siap memodifikasi model-model yang kita punyai tentang alam ini sejalan dengan penemuan-penemuan yang kita dapatkan".

Berdasarkan hasil observasi yang dilakukan di SD No. 1 Mengwitani serta wawancara bersama dengan wali kelas $\mathrm{V}$, didapatkan fakta bahwa hasil belajar IPA siswa kelas $V$ di SD No. 1 Mengwitani masih rendah dimana nilai ulangan harian yang memenuhi KKM, yaitu 75 hanya $50 \%$ dari 32 siswa yang memperoleh ketuntasan belajar. Ini memperlihatkan bahwa masih banyak siswa yang memiliki hasil belajar berada di bawah KKM yang telah ditentukan sekolah. Ketika observasi dilakukan saat guru mengajar, ditemukan bahwa dalam proses pembelajaran guru lebih banyak memberikan informasi dengan cara yang kurang menarik, serta kurangnya peran serta media yang digunakan. Kegiatan pembelajaran yang dilakukan hanya sebatas penjelasan materi, pemberian contoh dan soal-soal sebagai latihannya. Dengan proses pembelajaran seperti itu, mengakibatkan siswa menjadi kurang aktif dan tidak ada aktivitas siswa yang sangat berperan.

Kendala rendahnya hasil belajar IPA di kelas V SD No. 1 Mengwitani disebabkan banyaknya siswa yang mengalami kesulitan dalam memahami materi dan mengerjakan soal. Hal ini mungkin dikarenakan oleh konsep-konsep tentang materi ajar yang belum dikuasai dan sulit untuk diingat, mengingat pembelajaran IPA banyak menggunakan istilah-istilah ilmiah yang juga cukup menyulitkan siswa untuk mengingatnya. Oleh karena itu, guru harus berupaya membangkitkan motivasi belajar siswa dengan cara menggunakan atau menerapkan model pembelajaran yang melibatkan siswa secara aktif sehingga tidak hanya guru saja yang selalu meminta siswa untuk melakukan sesuatu dalam kegiatan pembelajaran untuk membuat siswa menjadi aktif. Salah satu model pembelajaran yang dapat digunakan untuk mengatasi masalah tersebut adalah Think Pair Share (TPS).

Kooperatif berasal dari bahasa Inggris yaitu cooperative yang artinya kerjasama. Menurut Made Wena pemelajaran kooperatif adalah sistem pembelajaran yang berusaha memanfaatkan teman sejawat (siswa lain) sebagai sumber belajar disamping guru dan sumber belajar lainya (Wena,2009). Pembelajaran kooperatif adalah pendekatan pembelajaran yang berfokus pada penggunaan kelompok kecil siswa untuk bekerja sama dalam memaksimalkan kondisi belajar untuk mencapai tujuan belajar (Junaedi,2008). Think "berfikir" pair "berpasangan" dan share "berbagi" (Widiastuti dan Ali, tt: 274). Sedangkan menurut Arends thinkpair-share atau berfikir-berpasanganberbagi merupakan jenis pembelajaran kooperatif yang diracang untuk mempengaruhipola interaksi siswa 
(Trianto, 2009). Model pembelajaran kooperatif tipe Think-Pair-Share (TPS) memberi kesempatan lebih kepada siswa untuk bekerja sendiri sekaligus bekerja sama dengan teman lainnya (Thobroni dan Mustafa, 2011). Kelemahannya menurut Basri (dalam Thobroni dan Mustafa, 2011), kelemahan Think-PairShare (TPS) antara lain: a) Memerlukan koordinasi secara bersamaan dari berbagai aktivitas, b) Memerlukan perhatian khusus dalam penggunaan rung kelas. c) Peralihan dari seluruh kelas ke kelompok kecil dapat menyita waktu pengajaran yang berharga. Untuk itu, guru harus membuat perencanaan yang seksama sehingga dapat meminimalkan jumlah waktu yang terbuang.

Think Pair Share (TPS) adalah pembelajaran kooperatif yang menggunakan struktur kelompok untuk mengembangkan kemampuan berpikir, berpasangan, dan berbagi yang memberikan kesempatan bagi siswa untuk mengembangkan kemampuan berpikir (Kunandar, 2010 \& Trianto, 2011). Tujuan dari pembelajaran kooperatif tipe Think Pair Share (TPS) yaitu untuk meningkatkan penguasaan akademik, mengajarkan keterampilan sosial dan membantu siswa untuk dapat berpikir kritis, serta meningkatkan pemahaman siswa dalam memahami konsep-konsep pembelajaran (Rusman, 2012).

Model Pembelajaran Kooperatif Tipe TPS adalah jenis pembelajaran kooperatif yang efektif untuk membuat variasi suasana pola diskusi kelas. Dengan asumsi bahwa semua resitasi atau diskusi membutuhkan pengetahuan untuk mengendalikan kelas secara keseluruhan dan memberi siswa untuk lebih banyak berpikir, untuk merespon dan saling membantu (Trianto, 2010).TPS adalah jenis pembelajaran kooperatif yang dirancang untuk memengaruhi pola interaksi siswa (Trianto, 2010).

Kurniasih dan Berlin Sani (2016) menyatakan bahwa "Model pembelajaran think-pair share (TPS) atau berpikir berpasangan berbagi adalah jenis pembelajaran kooperatif yang dirancang untuk mempengaruhi pola interaksi siswa. Model ini dikembangkan pertama kali oleh Frang Lyman dan Koleganya di universitas
Maryland". Prosedur yang digunakan dalam TPS dapat memberikan siswa lebih banyak waktu berpikir, untuk merespon dan saling bantu satu sama lain. Dengan metode ini siswa dilatih untuk mengutarakan pendapat dan menghargai pendapat orang lain dengan tetap mengacu kepada materi pembelajaran.

Berdasarkan uraian yang telah dipaparkan di atas, maka perlu dilaksanakan penelitian yang berjudul "Penerapan model pembelajaran Think Pair Share (TPS) untuk meningkatkan hasil belajar IPA siswa kelas V SD No. 1 Mengwitani tahun ajaran 2016/2017".

Berdasarkan latar belakang yang diuraikan di atas, maka rumusan masalah dalam penelitian ini adalah "Apakah penerapan Model Pembelajaran Think Pair Share (TPS) dapat meningkatkan hasil belajar IPA siswa kelas V SD No. 1 Mengwitani Tahun ajaran 2016/2017?". Berdasarkan permasalah dapat ditentukan tujuan penelitian yaitu untuk mengetahui peningkatan hasil belajar IPA siswa Kelas $\checkmark$ SD No. 1 Mengwitani Tahun ajaran 2016/2017 setelah penerapan model pembelajaran Think Pair Share (TPS).

Dalam model pembelajaran kooperatif siswa dibentuk menjadi kelompok-kelompok kecil yang terdiri dari empat sampai lima orang untuk bekerjasama dalam menguasai materi yang diberikan oleh guru. Adapun pengetian pembelajaran kooperatif menurut Slavin (dalam Tukiran, 2011) adalah "pembelajaran yang dilakukan secara berkelompok, siswa dalam satu kelas dijadikan kelompok-kelompok kecil yang terdiri dari 4 sampai 5 orang untuk memahami konsep yang difasilitasi guru". Model pembelajaran kooperatif adalah suatu pembelajaran melalui pembentukan kelompok-kelompok kecil dalam kelas. Artzt and Newman (dalam Trianto, 2014) menyatakan bahwa "dalam dalam belajar kooperatif siswa belajar bersama sebagai suatu tim dalam menyelesaikan tugas kelompok untuk mencapai tujuan bersama". Jadi setiap anggota kelompok memiliki tanggung jawab yang sama untuk keberhasilan kelompoknya.

Selama pembelajaran kooperatif siswa tetap tinggal dalam kelompoknya selama beberapa kali pertemuan. Mereka 
diajarkan keterampilan khusus agar dapat bekerja sama dengan baik di dalam kelompoknya seperti menjadi pendengar yang aktif, memberikan penjelasan kepada teman satu kelompok dengan baik dan berdiskusi. Dalam pembelajaran kooperatif belajar belum selesai apabila ada salah satu kelompok yang belum menguasai materi. Isjoni, (2013) menyatakan "pembelajaran kooperatif adalah suatu model pembelajaran yang saat ini banyak digunakan untuk mewujudkan kegiatan belajar mengajar yang berpusat pada sisiwa (student oriented), terutama untuk mengatasi permasalahan yang ditemukan guru dalam mengaktifkan siswa, yang tidak dapat bekerja sama dengan orang lain, siswa yang agresif dan tidak peduli pada yang lain.

Menurut Eggen and Kauchak (dalam Trianto, 2014) menyatakan "pembelajaran kooperatif merupakan suatu kelompok strategi pengajaran yang melibatkan siswa bekerja secara berkolaborasi untuk mencapai tujuan bersama". Dengan pembelajaran kooperatif diharapkan siswa mampu bekerja sama untuk belajar dan bertanggung jawab pada kemajuan belajar temannya. Oleh karena itu, dalam pembelajaran kooperatif siswa harus bisa menyingkirkan rasa egoisnya untuk bisa memahami materi pembelajaran sendiri. Rasa solidaritas dikalangan siswa dapat dikembangkan sehingga kelak akan muncul generasi baru yang memiliki prestasi akademik yang cemerlang dan memiliki solidaritas yang kuat.

Adapun beberapa contoh model pembelajaran kooperatif antara lain: 1) Jigsaw Menurut Shoimin (2014) "Model pembelajaran kooperatif jigsaw menitik beratkan pada kerja kelompok kecil. Model ini merupakan model belajar kooperatif dengan cara siswa belajar dalam kelompok kecil yang terdiri dari empat sampai enam orang secara heterogen". 2) Student Team Achievement Divisions (STAD) / Divisi Pencapaian-Kelompok, Isjoni, (2009) menyatakan "Pembelajaran kooperatif tipe STAD merupakan salah satu tipe dari model pembelajaran kooperatif dengan menggunakan kelompok-kelompok kecil dengan jumlah anggota tiap kelompok 4-5 orang siswa secara heterogen". 3) Investigasi Kelompok /Group Investigation (GI), Kurniasih dan Berlin Sani (2016) menyatakan "Model pembelajaran Group Investigation adalah salah satu bentuk model pembelajaran kooperatif yang memiliki titik tekan pada partisipasi dan aktivitas siswa untuk mencari sendiri materi atau segala sesuatu mengenai materi pelajaran yang akan dipelajari”. 1) Think-Pair-Share (TPS), Trianto (2007) menyatakan "Think-Pair-Share (TPS) atau berikir berpasangan berbagi adalah merupakan jenis pembelajaran kooperatif yang dirancang untuk mempengaruhi pola interaksi siswa". 2) Teams Games Tournaments (TGT), Menurut Slavin (dalam Tukiran, dkk, 2011) "TGT menggunakan turnamen akademik, dan menggunakan kuis-kuis sistem skor kemajuan individu, dimana para siswa berlomba sebagai wakil tim mereka dengan anggota tim lain yang kinerja akademik sebelumnya setara seperti mereka".

Penyelesaian permasalah yang dihadapi siswa di dalam model pembelajaran kooperatif memang dihadapi dan diselesaikan bersama-sama dengan anggota kelompoknya masing-masing . Namun bukan berarti peran guru menjadi tidak penting. Peran guru masih sangat diperlukan guna mengawasi jalannya kegiatan pembelajaran agar tidak keluar dari topik yang dibicarakan. Guru juga bertugas membimbing siswa dan kelompok yang mengalami hambatan atau permasalahan dalam memecahkan dan menyelesaikan masalahnya. Disamping itu peran guru dalam hal ini adalah mengarahkan agar tercipta kondisi yang baik dalam pembelajaran dan memberikan motivasi kepada seluruh siswa.

Berdasarkan uraian yang dipaparkan diatas maka tipe pembelajaran kooperatif think pair share dirasa sesuai untuk digunakan. Model ini baik digunakan bagi guru yang baru pertama kali menggunakan pendekatan kooperatif dan bagi siswa model ini dirasa sangat baik untuk memotivasi seluruh siswa ikut terlibat aktif di dalam setiap kegiatan pembelajaran. 
Kurniasih dan Berlin Sani (2016) menyatakan bahwa "model pembelajaran think-pair share atau berpikir berpasangan adalah jenis pembelajaran kooperatif yang dirancang untuk mempengaruhi pola interaksi siswa. Model ini dikembangkan pertama kali oleh Frang Lyman dan Koleganya di universitas Maryland". Arends (dalam Badar, 2014) menyatakan bahwa "Think Pair Share merupakan cara yang efektif untuk membuat variasi suasana pola diskusi kelas. Dengan asumsi bahwa semua resitasi atau diskusi membutuhkan pengaturan untuk mengendalikan kelas secara keseluruhan, dan prosedur yang digunakan dalam think pair share memberikan siswa lebih banyak waktu untuk berpikir".

Model ini memperkenalkan ide waktu berpikir atau waktu tunggu yang menjadi faktor kuat dalam meningkatkan kemampuan siswa dalam merespon pertanyaan. Model pembelajaran TPS ini dapat digunakan pada semua mata pelajaran dan pada semua tingkatan usia didik. Artinya model pembelajaran ini cocok untuk diterapkan pada pembelajaran untuk anak usia sekolah dasar.

TPS memiliki prosedur yang secara eksplisit memberi siswa waktu untuk berpikir, menjawab, saling membantu satu sama lain. Dengan demikian diharapkan siswa mampu bekerjasama, saling membutuhkan satu sama lain, dan saling bergantung pada kelompok kecil secara kooperatif.
Adapun komponen-komponen dalam model pembelajaran think pair share adalah sebagai berikut, pertama Berpikir (Think), pelaksanaan pembelajaran TPS diawali dari berpikir sendiri mengenai pemecahan suatu masalah. Tahap berpikir menuntut siswa untuk lebih tekun belajar dan aktif mencari refrensi agar lebih mudah dalam memecahkan masalah atau soal yang diberikan guru. Keduan Berpasangan (Pair), setelah diawali dengan berpikir, siswa kemudian diminta untuk mendiskusikan hasil pemikirannya secara berpasangan. Tahap diskusi merupakan tahap menyatukan pendapat masingmasing siswa guna memperdalam pengetahuan mereka. Diskusi dapat mendorong siswa aktif menyampaikan pendapat dan mendengarkan pendapat orang lain kelompok serta mampu bekejasama dengan orang lain. Ketiga Berbagi (Share), setelah mendiskusikan hasil pemikirannya, pasangan-pasangan siswa yang ada diminta untuk berbagi hasil pemikiran yang telah dibicarakan bersama pasangannya masing-masing kepada seluruh kelas. Tahap berbagi menuntut siswa untuk mampu mengungkapkan pendapatnya secara bertanggung jawab, serta mampu mempertahankan pendapat yang telah disampaikannya

Adapun langkah-langkah yang digunakan dalam model pembelajaran think pair.

Tabel 1. Fase-fase Pembelajaran Think Pair Share

$\begin{array}{ll}\text { Langkah } 1 & \begin{array}{l}\text { Berpikir (Thinking) } \\ \text { Guru mengajukan suatu pertanyaan atau masalah yang dikaitkan dengan } \\ \text { pelajaran, dan meminta siswa menggunakan waktu beberapa menit untuk } \\ \text { berpikir sediri jawaban atau masalah. }\end{array} \\ \text { Lerpasangan (Pairing) } \\ \text { Selanjutnya guru meminta siswa untuk berpasangan dan mendiskusikan } \\ \text { apa yang telah mereka peroleh. Interaksi selama waktu yang disediakan } \\ \text { dapat menyatukan jawaban jika suatu pertanyaan yang diajukan, atau } \\ \text { menyatukan gagasan apabla suatu masalah khusus yang diidentifikasi. } \\ \text { Secara normal guru member waktu tidak lebih dari } 4 \text { atau } 5 \text { menit untuk } \\ \text { berpasangan. } \\ \text { Berbagi (Sharing) } \\ \begin{array}{l}\text { Pada langkah akhir guru meminta pasangan untuk berbagi dengan } \\ \text { keseluruhan kelas yang telah mereka bicarakan. Hal ini efektif untuk } \\ \text { berkeliling ruangan dari pasangan ke pasangan lainnya dan melanjutkan }\end{array}\end{array}$


sampai sekitar sebagian pasangan mendapatkan keasempatan untuk melaporkan

Sumber : Arends, 1997 disadur Tjokrodihardjo, 2003 (dalam Badar, 2014)

Model pembelajaran TPS ini memberikan kesempatan kepada siswa untuk berperan aktif dalam proses pembelajaran. Dengan aktifnya siswa maka suasana kelas juga akan menjadi lebih kondusif yang mana tentu saja akan berdampak baik bagi siswa-siswa lainnya yang masih enggan untuk ikut serta dalam kegiatan pembelajaran yang disebabkan oleh faktor-faktor tertentu seperti masih canggung atau merasa malu untuk mengungkapkan pendapatnya karena takut salah atau kurang merasa percaya diri akan pendapat yang dimilikinya sendiri. Model pembelajaran ini akan membuat siswa mau tidak mau akan mengeluarkan pendapatnya dengan cara berbagi walaupun sementara waktu untuk sebatas dengan teman sebangku sebagai partner. Namun hal ini tentu menjadi titik kemajuan bagi anak yang nantinya akan menumbuhkembangkan keberaniannya untuk berbicara, mengungkapkan pendapatnya kepada lingkup yang lebih besar, yakni teman sekelasnya.

Proses pembelajaran akan berjalan dengan lancar apabila terjadi interaksi dua arah, bukan dari satu arah. Dua arah yang dimaksud adalah baik dari guru kepada siswa, dari siswa kepada guru ataupun dari siswa satu ke siswa lainnya. Tentu saja, hal ini akan membuat proses pembelajaran menjadi lebih interaktif dan bervariasi mengingat kemampuan yang dimiliki setiap siswa tidak akan sama. Melalui model pembelajaran TPS setiap siswa akan menjadi pelengkap pada siswa lainnya. Pelengkap yang dimaksud adalah pelengkap dalam proses pembelajaran. Pemikiran yang berbeda dari setiap siswa akan disatukan ketika siswa berpasangan menggabungkan ide-ide yang mereka dapat yang mungkin tidak dimiliki atau terpikirkan oleh masing-masing individu sebelumnya. Sehingga keduanya akan saling memberikan dampak yang positif dan saling menguatkan satu sama lain.

$$
\text { Sagala (2012) menyebutkan }
$$

bahwa, "pembelajaran mengandung arti setiap kegiatan yang dirancang untuk membantu seseorang mempelajari suatu kemampuan dan atau nilai yang baru". Pembelajaran IPA di Sekolah Dasar bertujuan untuk mempersiapkan siswa agar sanggup menghadapi perubahanperubahan di dalam kehidupan dan dunia yang sedang berkembang. Dengan kata lain, IPA mengharapkan siswa untuk dapat meningkatkan kemampuannya dalam menyesuaikan diri dengan perubahanperubahan yang terjadi disekitarnya dan memasuki dunia teknologi, termasuk teknologi informasi. Mata pelajaran IPA di Sekolah Dasar diberikan kepada siswa dengan tujuan agar siswa memiliki kemampuan berpikir logis, analisis, sistematis, kritis dan kreatif serta kemampuan bekerja sama.

Dalam pembelajaran IPA guru dituntut untuk dapat mengajak anak didiknya memanfaatkan apa yang ada di alam sekitar mereka sebagai sumber belajar. Hal ini dimaksudkan bahwa alam sekitar memiliki banyak hal yang tidak akan habis digunakan dan untuk dipelajari. Namun bukan berarti sumber belajar lain seperti buku teks tidak penting. Buku teks merupakan bagian penting di dalam pembelajaran IPA. Didalam buku teks anak-anak akan dapat mengetahui atau mendapatkan informasi terkait dengan fenomena-fenomena atau fakta-fakta yang mereka jumpai di alam sekitar yang tidak mereka pahami maksudnya di dalam proses pembelajaran IPA.

Belajar merupakan aktivitas manusia yang sangat vital dan secara terus-menerus akan dilakukan selama manusia tersebut masih hidup. Manusia tidak mampu hidup sebagai manusia jika ia tidak dididik atau diajar oleh manusia lainnya. Thobroni (2011) menyatakan "belajar merupakan proses yang bersifat internal (a purely internal event) yang tidak dapat dilihat dengan nyata. Proses ini terjadi di dalam diri seseorang yang sedang mengalami proses belajar". Proses kegiatan yang begitu panjang akan memberikan perubahan yang relatif permananen. Dalam proses belajar yang 
panjang tersebut tentu terdapat pengalaman-pengalaman serta latihanlatihan yang akan menguatkan seseorang untuk mendapatkan hasil belajar yang akan melekat lebih lama.

Sudjana (2010) menyatakan "hasil belajar adalah kemampuan-kemampuan yang dimiliki siswa setelah ia menerima pengalaman belajarnya". Hasil belajar ditandai dengan perubahan tingkah laku. Walaupun tidak semua perubahan tingkah laku merupakan hasil belajar, akan tetapi aktivitas belajar umumnya disertai dengan perubahan tingkah laku. Perubahan tingkah laku sebagai hasil belajar juga dapat menyentuh perubahan pada aspek afektif, termasuk pada perubaha aspek emosional. Perubahan ini biasanya tidak dapat dilihat dalam waktu yang singkat, akan tetapi sering kali dalam waktu yang lama.

2011) "hasil belajar mencakup kemampuan kognitif, afektif dan psikomotorik". Kawasan kognitif berkenaan dengan ingatan atau pengetahuan dan kemampuan intelektual serta keterampilan-keterampilan. Kawasan afektif menggambarkan sikap, minat, dan nilai serta pengembangan pengertian atau pengetahuan dan penyesuaian diri yang memadai. Kawasan psikomotor adalah kemampuan-kemampuan menggiatkan dan mengkoordinasikan gerak.

Aunurrahman (2012) menyatakan ada beberapa faktor yang dapat mempengaruhi hasil belajar siswa, yaitu: pertama Faktor Guru, Dalam proses pembelajaran kehadiran guru masih menempati posisi yang penting. Dalam ruang lingkup tugasnya, guru dituntut untuk memiliki keterampilan terkait dengan tugas-tugas yang dilaksanakannya. Pengenalan terhadap siswa sebelum interaksi mengajar juga merupakan hal penting yang harus dilakukan guru. Dengan begitu guru dapat menentukan metode yang tepat untuk melakukan kegiatan belajar mengajar terhadap siswa tersebut. Kedua Faktor siswa, Setiap siswa mempunyai keragaman dalam hal kecakapan maupun kepribadian. Kecakapan yang dimiliki masing-masing itu meliputi kecakapan potensial maupun kecakapan yang diperoleh dari hasil belajar. Ketiga Lingkungan Sosial , Lingkungan sekolah sebagai lingkungan sosial dapat memberikan pengaruh positif dan negatif terhadap siswa. Lingkungan sosial yang tidak menguntungkan perkembangan siswa dapat memberi pengaruh negative terhadap kegiatan belajar siswa yang tentu akan berpengaruh pada hasil belajar siswa tersebut. Keempat Kurikulum sekolah, Kurikulum merupakan acuan untuk mengambangkan proses pembelajaran. Maka dari itu kurikulum senantiasa menyesuaikan dengan perubahan yang terjadi agar tetap sesuai dengan kebutuhan yang dibutuhkan peserta didik.

Berdasarkan pemaparan di atas dapat disimpulkan bahwa ada dua faktor yang mempengaruhi hasil belajar yaitu faktor internal dan faktor eksternal. Faktor internal sendiri berasal dari dalam diri siswa. Sedangkan faktor eksternal berasal dari luar diri siswa seperti yang telah dikemukakan di atas.

\section{Metode}

Jenis penelitian yang dilaksanakan adalah penelitian tindakan kelas (Classroom Action Research). Penelitian tindakan kelas ini memilki empat tahapan pada satu siklus penelitian. Keempat tahapan tersebut terdiri dari: perencanaan, tindakan, observasi/evaluasi, dan refleksi. Penelitian tindakan kelas ini dilaksanakan di SD No. 1 Mengwitani pada semester I tahun pelajaran 2016/2017. Subjek penelitian adalah siswa kelas $\mathrm{V}$ Tahun Pelajaran 2016/2017 dengan jumlah siswa 32 orang terdiri atas 16 orang siswa lakilaki dan 16 orang siswa perempuan. Sedangkan objek penelitian ini adalah hasil belajar IPA siswa.

Adapun metode pengumpulan data yang digunakan dalam penelitian ini adalah metode tes. Data hasil belajar matematika dikumpulkan melalui tes tertulis objektif berbentuk pilihan ganda biasa dengan 4 options berjumlah 20 butir soal. Metode analisis data penelitian ini menggunakan metode deskriptif kuantitatif.

Skor masing-masing siswa dihitung dengan rumus:

$$
\text { Skor }=\frac{\text { Skor yang diperoleh }}{\text { Skor maksimal }} \times 100
$$


(1) Rata-rata hasil belajar siswa dihitung dengan rumus:

$$
X=\frac{\sum x}{N}
$$

(3) Ketuntasan belajar siswa secara klasikal dapat dihitung menggunakan rumus:

Ketuntasan Belajar $=\frac{n \geq 75}{N} \times 100 \%$
(2) Persentase rata-rata hasil belajar dihitung dengan rumus:

$M \%=\left[\frac{M}{S M I}\right] \times 100 \%$

Untuk mengetahui kategori hasil belajar siswa, persentase rata-rata hasil belajar yang telah diperoleh dengan menggunakan rumus dapat dikonversikan ke dalam tabel kategori penskoran acuan patokan (PAP) Agung (2014).

Tabel 2. Kategori Penilaian Acuan Patokan (PAP)

\begin{tabular}{cc}
\hline Persentase Penguasaan & Kategori \\
\hline $90-100$ & Sangat tinggi \\
$80-89$ & Tinggi \\
$65-79$ & Sedang \\
$55-64$ & Rendah \\
$0-54$ & Sangat rendah \\
\hline
\end{tabular}

Adapun indikator keberhasilan penelitian ini adalah persentase rata-rata hasil belajar siswa pada mata pelajaran IPA mencapai kategori tinggi (80\%-89\%) dengan ketuntasan belajar siswa mencapai $75 \%$.

\section{Hasil Dan Pembahasan}

Penelitian ini dilaksanakan dalam 2 siklus, dimana setiap siklus dilaksanakan dalam 4 kali pertemuan. Dari 4 kali pertemuan tersebut, 3 kali merupakan pertemuan untuk kegiatan pembelajaran dan 1 kali untuk kegiatan evaluasi tes hasil belajar pengetahuan IPA. Adapun jumlah subjek penelitian ini adalah sejumlah 32 orang yang merupakan siswa kelas $\mathrm{V}$ SD No. 1 Mengwitani tahun ajaran 2016/2017.

Pada siklus I dilaksanakan empat kali pertemuan, terdiri dari tiga kali pertemuan proses pembelajaran dan satu kali pertemuan untuk evaluasi. Pertemuan pertama hari Selasa, 11 Oktober 2016, pertemuan kedua hari Jumat, 14 Oktober 2016, pertemuan ketiga dilaksanakan pada hari Selasa, 18 Oktober 2016 dan untuk evaluasi hasil belajar matematika dilaksanakan pada hari Jumat, 21 Oktober 2016 dengan menggunakan intrumen tes.
Setelah dilakukan analisis dari data hasil belajar IPA siswa pada siklus I, diperoleh persentase rata-rata hasil belajar sebesar $75,31 \%$. Setelah dikonversikan pada kriteria hasil belajar IPA, persentase rata-rata hasil belajar IPA siswa sebesar $75,31 \%$ berada pada rentang 65\%-79\%, yang mana termasuk dalam kriteria hasil belajar sedang dengan ketuntasan belajar yang diperoleh sebesar $65,62 \%$. Dari 32 orang siswa hanya 21 orang siswa yang tuntas dan 11 orang siswa belum tuntas. Walaupun sudah mengalami peningkatan dibandingkan dengan kondisi awal, namun hasil yang diperoleh belum mencapai indicator keberhasilan yang ditetapkan dalam penelitian kali ini. Hal ini mengakibatkan diperlukannya perbaikan pada proses pembelajaran IPA dengan melaksanakan siklus ke II.

Siklus II dilaksanakan dalam empat kali pertemuan, terdiri dari tiga kali pertemuan proses pembelajaran dan satu kali pertemuan evaluasi. Selasa, 25 Oktober 2016, pertemuan kedua hari Jumat, 28 Oktober 2016, pertemuan ketiga dilaksanakan pada hari Selasa, 1 November 2016 dan untuk evaluasi hasil 
belajar matematika dilaksanakan pada hari Jumat, 4 November 2016 dengan menggunakan intrumen tes.

Dalam pelaksanaan proses pembelajaran pada siklus ke II ini, pada setiap pertemuan diupayakan adanya inovasi dan perbaikan. Perbaikanperbaikan yang dilakukan berdasarkan atas kendala yang dihadapi pada siklus I. Dengan adanya inovasi dan perbaikan pada siklus ini, diharapkan proses pembelajaran dapat berjalan lebih optimal dan dapat membantu siswa mencapai hasil belajar yang lebih baik sehingga indikator keberhasilan yang ingin dicapai pada penelitian ini dapat tercapai.

Pelaksanaan tindakan pada siklus II ini merupakan tindak lanjut dari hasil refleksi pada siklus I. Kendala-kendala dan hambatan yang ditemui pada siklus I yang menghambat pencapaian ketuntasan belajar IPA siswa diperbaiki di siklus ini. Berdasarkan hasil yang telah dicapai pada siklus ke II, terjadi peningkatan persentase rata-rata hasil belajar IPA siswa sebesar $4,84 \%$ dengan perolehan pada siklus I sebesar $75,31 \%$ dan pada siklus II meningkat menjadi $80,15 \%$ dan persentase ketuntasan belajar siswa sebesar $21,88 \%$, yang mana pada siklus I hasil persentase ketuntasan belajar siswa sebesar 65,62\%, pada siklus ke II meningkat menjadi $87,5 \%$. Adapun hasil yang telah diperoleh siswa memenuhi target yang ditentukan dalam penelitian ini. Sehingga pelaksanaan tindakan sudah cukup dilakukan dalam dua siklus.

Hasil setelah diberikan tindakan pada siklus II, sudah mengalami peningkatan pada persentase rata-rata hasil belajar siswa berada pada kategori tinggi (80\%-89\%) dengan ketuntasan belajar sebesar $75 \%$. Berdasarkan data yang diperoleh pada siklus II menunjukkan bahwa indikator keberhasilan yang diharapkan dalam penelitian ini sudah terpenuhi. Hal ini dapat disimpulkan bahwa melalui penerapan model pembelajaran think pair share dapat meningkatkan hasil belajar IPA siswa kelas V SD No. 1 Mengwitani tahun ajaran 2016/2017. Peningkatan hasil belajar ini dapat dijadikan sebagai indikator minat siswa untuk mengikuti pembelajaran semakin membaik dan meningkat. Walaupun demikian, bukan berarti pembelajaran yang dilaksanakan dalam penelitian ini sangat sempurna. Kedepannya, inovasi dan ide-ide baru dalam pembelajaran tetap diperlukan untuk menjaga situasi pembelajaran tetap kondusif.

Untuk memudahkan dalam mengetahui peningkatan data tentang hasil belajar siswa terhadap mata pelajaran matematika pada siklus I dan siklus II, maka dibuatlah ringkasan hasil penelitian sebagai berikut.

Tabel 3. Ringkasan Hasil Penelitian tentang Hasil Belajar IPA Siswa pada Siklus I dan Siklus II

\begin{tabular}{ccc}
\hline Tahapan & $\begin{array}{c}\text { Persentase Rata-Rata } \\
\text { Hasil Belajar }\end{array}$ & $\begin{array}{c}\text { Persentase } \\
\text { Ketuntasan Belajar }\end{array}$ \\
\hline Siklus I & $75,31 \%$ & $65,62 \%$ \\
Kategori & Sedang & Sedang \\
Siklus II & $80,15 \%$ & $87,5 \%$ \\
Kategori & Tinggi & Tinggi \\
\hline
\end{tabular}

Penelitian tindakan kelas ini menerapkan model pembelajaran kooperatif think pair share (TPS) yang dilaksanakan di SD No. 1 Mengwitani pada kelas $\mathrm{V}$ tahun ajaran 2016/2017. Penelitian tindakan kelas ini telah dilaksanakan dalam 2 siklus. Setiap siklus terdiri atas 4 pertemuan, dimana 3 pertemuan merupakan tatap muka untuk belajar dengan menerapkan model pembelajaran yang dimaksud dan 1 pertemuan untuk mengadakan evaluasi dengan memberikan tes guna mengetahui peningkatan hasil belajar siswa. 
Berdasarkan hasil pengamatan, hasil pembelajaran IPA di SD No. 1 Mengwitani khususnya pada kelas $\mathrm{V}$ sebelum diterapkannya model pembelajaran TPS dalam kategori rendah. Pada siklus pertama pembelajaran dengan penerapan model pembelajaran TPS persentase hasil belajar siswa meningkat, dengan jumlah persentase rata-rata hasil belajar sebesar 75,31\% dengan kategori sedang dan ketuntasan belajar sebesar $65,62 \%$. . Walaupun telah terjadi peningkatan hasil belajar, namun belum mencukupi indikator keberhasilan yang ditetapkan. Hal ini disebabkan oleh adanya beberapa kendala dan kekurangan yang ditemui pada saat proses pelaksanaan kegiatan pembelajaran pada siklus I.

Adapun kendala-kendala yang ditemui pada saat pelaksanaan siklus I secara umum adalah (1) Siswa masih merasa canggung untuk belajar secara berpasangan. Hal ini disebabkan siswa memang belum terbiasa untuk menerima kehadiran orang lain yang bukan teman akrabnya untuk berpasangan dan berbagi. Hal ini juga disebabkan masih adanya rasa malu untuk berbagi terutamanya ketika dihadapkan pada masalah gender. Ketika pasangan satu bangku berbeda gender akan lebih sulit untuk berkomunikasi walaupun siswa ini sudah lama menjadi teman sekelas. Faktor kedekatan antar siswa juga berpengaruh dalam hal ini. Siswa cenderung memiliki teman baik sejak mereka duduk di bangu kelas rendah. Faktor ini juga membuat siswa cenderung akan memilih teman akrabnya atau kelompok teman yang memiliki kedekatan dengan siswa tersebut saat guru meminta membentuk kelompok atau mencari pasangan. Dalam model pembelajaran ini, siswa dipasangkan dengan teman sebangku yang tidak selalu teman akrabnya sehingga menyebabkan siswa canggung untuk berbagi; (2) Siswa yang mendominasi kegiatan pembelajaran adalah siswa yang pintar dan terampil dalam menyampaikan pendapat. Hal ini diakibatkan karena siswa yang terampil dalam menyampaikan pendapatnya cenderung lebih percaya diri atau memiliki rasa percaya diri yang lebih dibandingkan dengan siswa yang lain yang cenderung pasif; (3) Sebagian siswa masih merasa malu untuk menyampaikan pendapatnya yang disebabkan karena rasa kurang percaya diri untuk tampil di depan umum. Hal ini terjadi karena rasa takut yang terlalu mendominasi didalam diri siswa yang membuat siswa menjadi ragu untuk mencoba mengungkapkan pendapatnya sekalipun pendapat yang dimilikinya sama seperti yang dimiliki siswa yang memiliki rasa percaya diri yang tinggi, serta (4) Masih ditemukan kendala dalam alokasi waktu, hal ini disebabkan karena kurangnya disiplin siswa dalam mengerjakan tugas sesuai dengan waktu yang telah diberikan. Terkadang dalam setiap pertemuan guru telah merancang pertemuan dengan sedimikian rupa berserta dengan alokasi waktu yang diberikan. Namun, dalam perjalanannya sering kali alokasi waktu tersebut tidak dapat tercapai dengan baik dikarenakan adanya hambatan dari pihak siswa seperti kurang disiplinnya siswa. Seperti ketika ada siswa yang sudah selesai mengerjakan tugas terlebih dahulu cenderung akan menggunakan waktu luangnya untuk berbicara dengan siswa lain yang juga sudah selesai dalam mengerjakan tugas, yang menyebabkan suasana kelas menjadi gaduh dan mengganggu konsentrasi siswa lainnya. Selain itu siswa juga masih sering mengganggu teman terdekatnya ketika mereka merasa ragu dengan apa yang telah dilakukannya walaupun sudah ada petunjuk pengerjaan tugas dari guru baik secara lisan maupun tertulis. Hal ini tentu saja akan menghambat siswa lainnya dalam menyelesaikan tugasnya masingmasing yang berdampak pada tidak tepat alokasi waktu yang telah ditentukan.

Berdasarkan hasil yang telah didapat dari siklus I, maka perlu diadakan siklus ke II guna meningkatkan hasil belajar siswa dan melengkapi kekurangan yang ada pada siklus I. Pada siklus ke II, hasil pembelajaran IPA dengan penerapan model pembelajaran TPS ini menunjukkan peningkatan persentase rata-rata hasil belajar IPA siswa sebesar $80,15 \%$ dengan persentase ketuntasan belajar sebesar $87,5 \%$. Secara umum, pada siklus ke II, kendala-kendala yang dijumpai ketika dilaksanakannya pembelajaran pada 
siklus I mulai berkurang. Hal ini dapat dilihat dalam berlangsungnya kegiatan pembelajaran (1) Sebagian besar siswa sudah berani mengungkapkan pendapatnya dan jumlah siswa yang pasif berkurang jauh jumlahnya seperti yang ditemukan pada siklus I, hal ini disebabkan karena secara perlahan siswa mulai bisa menerima kehadiran pasangan kelompoknya walaupun berbeda gender dan bukan teman dekatnya. Siswa juga mulai berani berpendapat karena setelah berjalannya waktu siswa sadar setiap pendapat yang mereka sampaikan selalu mendapat penghargaan dari guru; (2) Siswa mulai terbiasa dengan proses pembelajaran yang menerapkan model kooperatif think pair share yang mana menuntut siswa untuk melakukan kegiatan pembelajaran secara berpasangan dan menuntut siswa untuk saling bertukar pikiran dan menghargai pendapat yang diungkapkan pasangannya tanpa membeda-bedakan kemampuan yang dimiliki setiap individu. Hal ini juga berdampak pada makin aktifnya siswa dalam kegiatan pembelajaran.

Hal ini juga sejalan dengan penelitian yang dilakukan oleh Jasdilla (2016) yang menyatakan bahwa model pembelajaran kooperatif tipe Think, Pair, Share (TPS) dapat meningkatkan hasil belajar IPS di kelas IV sekolah dasar. Dengan dihargainya setiap pendapat keberanian siswa mulai tumbuh untuk terbiasa berpendapat dan memberikan sumbangan pikirannya tidak hanya untuk dirinya sendiri tapi juga untuk rekan atau teman-temannya; (3) Siswa mulai disiplin dalam mengerjakan tugas dengan waktu yang telah diberikan sehingga kegiatan pembelajaran berlangsung aman dan kondusif. Hal ini disebabkan mulai sadarnya siswa akan sikap tidak disiplin yang juga merugikan dirinya sendiri.

Penerapan model pembelajaran TPS ini secara tidak langsung melatih siswa untuk menumbuhkan rasa percaya dirinya serta mengembangkan kemampuannya dalam berbagi informasi dan menyampaikan pendapat serta mengemukakan ide yang mereka miliki, yang menyebabkan suasana kelas menjadi kondusif dan menyenangkan. Hal ini sejalan dengan hasil peneitian yang dilakukan oleh Widiana ( 2014) disimpulkan bahwa penerapan model pembelajaran kooperatif tipe think pair square berpengaruh positif terhadap hasil belajar Matematika siswa kelas $\mathrm{V}$ di Gugus I Nakula Kecamatan Negara. Model pembelajaran ini juga membantu siswa untuk pemahaman konsep dan materi pelajaran dan menggali kemampuan dalam hal informasi dan pengetahuan yang dimilikinya secara mandiri dan berpasangan. Dengan begitu, informasi yang didapat oleh siswa tidak hanya sebatas apa yang mereka miliki sendiri, tetapi juga akan bertambah dengan informasi yang diberikan atau disampaikan oleh pasangannya akan saling melengkapi satu sama lain sehingga akan menghasilkan pemahaman yang lebih baik terhadap materi atau informasi yang dimiliki. Berdasarkan hal tersebut dapat dikatakan bahwa pembelajaran IPA dengan model pembelajaran kooperatif think pair share dapat meningkatkan hasil belajar IPA siswa kelas V SD No, 1 Mengwitani.

\section{Simpulan Dan Saran}

Berdasarkan hasil penelitian dan pembahasan yang telah diuraikan, dapat ditarik kesimpulan, yaitu model pembelajaran think pair share dapat meningkatkan hasil belajar IPA siswa kelas V SD No. 1 Mengwitani tahun ajaran 2016/2017. Hal itu terlihat dari hasil tindakan pada siklus I dan II yang telah mengalami peningkatan persentase ratarata hasil belajar siswa pada siklus I mencapai $75,31 \%$ dengan kategori sedang dan pada siklus II persentase ratarata hasil belajar meningkat menjadi $80,15 \%$ dengan kategori tinggi. Dengan ketuntasan belajar siswa pada siklus I sebesar $65,62 \%$ dan pada siuklus II mencapai $87,5 \%$ sehingga telah tercapai indikator keberhasilan sebesar $75 \%$.

Berdasarkan simpulan di atas, dapat disampaikan beberapa saran sebagai berikut kepada pihak sekolah disarankan agar hasil dari penelitian ini dapat dijadikan sebagai salah satu refrensi atau informasi tambahan dalam mengambil kebijakan dalam upaya meningkatkan hasil belajar siswa, guru disarankan agar dapat menerapkan model 
pembelajaran think pair share ini dalam pembelajaran dikelas tidak hanya pada pembelajaran IPA namun juga pada pembelajaran lainnya. Siswa agar senantiasa menjaga suasana pembelajaran yang kondusif dan menjaga kemajuan dalam pembelajaran yang telah dicapai setelah penelitian ini untuk terus dilakukan dikemudian hari.

\section{Daftar Pustaka}

Agung, A.A Gede. 2014. Buku Ajar Metodologi Penelitian Pendidikan. Yogyakarta : Aditya Media Publising

Aunurrahman. 2012. Belajar dan Pembelajaran. Bandung : Alfabeta.

Badar, Trianto Ibnu. 2014. Mendesain Model Pembelajaran Inovatif, Progresif, dan kontekstual. Jakarta : Kencana.

Haryono. 2013. Pembelajaran IPA yang Menarik dan Mengasyikkan. Yogyakarta : Kepel Press.

Isjoni. 2013. Cooperative Learning. Bandung: Alfabeta.

Jasdilla. 2016. Hasil Belajar Dan Pembelajaran Kooperatif Tipe Think Pair Share (Tps). Journal Pendidikan Indonesia P-ISSN: 2303288X E-ISSN: 2541-7207 Vol. 6, No.1, April 2016. http://ejournal.undiksha.ac.id/index.p $\mathrm{hp} / \mathrm{JPI} /$ article/view/9253/6328

Junaedi, dkk. 2008. Strategi Pembelajaran. Edisi Pertama. Surabaya: LAPIS-PGMI.

Kunandar. 2007. Implementasi kurikulum tingkat satuan pendidikan kemandirian guru dan kepala sekolah. Jakarta: Bumi Aksara.

Kurniasih, Imas \& Berlin Sani.2016. Ragam Pengembangan Model Pembelajaran Untuk Peningkatan Profesionalitas Guru.Jogjakarta: Kata Pena.

Rusman. 2012. Model-model pembelajaran. Jakarta: Raja Grafindo Persada.

Sagala, Syaiful. 2012. Konsep dan Makna Pembelajaran. Bandung : Alfabeta.

Sudjana, Nana. 2010. Penilaian Hasil Proses Belajar Mengajar. Bandung : Sinar Biru.
Shoimin, Aris. 2014. 68 Model Pembelajaran Inovatif dalam Kurikulum 2013.Yogyakarta : ArRuzz Media.

Taniredja, Tukiran. 2011. Model-Model Pembelajaran Inovatif. Bandung : Alfabeta.

Thobroni, Muhammad \& Arif Mustofa. 2011. Belajar dan Pembelajaran. Yogyakarta : Ar-Ruzz Media.

Trianto. 2009. Mendesain Model Pembelajaran Inovatif-Progresif. Jakarta : Kencana.

------. 2011. Mendesain model pembelajaran inovatif-progresif. Jakarta:Pernada Media Group. 2012. Model Pembelajaran Terpadu. Jakarta: PT. Bumi Aksara.

Wena, Made. 2009. Strategi Pembelajaran Inovatif Kontemporer: Suatu Pendekatan Konseptual Operasional. Jakarta: Bumi Aksara.

Widiaastuti dan Ali K. tt. Grand Kamus Inggris-Indonesia Indonesia- Inggris. Surabaya: Apollo.

Widiana, dkk. 2014. Pengaruh Model Pembelajaran Kooperatif Tipe Think Pair Square (Tps) Berbantuan Kartu Kerja Terhadap Hasil Belajar Matematika. Jurnal Mimbar PGSD Universitas Pendidikan Ganesha Jurusan PGSD (Vol: 2 No: 1 Tahun 2014). 